

\section{Commercial Ventures in Nonprofit Organizations: Strategic Change or Natural Evolution?}

This paper investigates the change processes involved in establishing commercial ventures as revenue generating alternatives in eleven nonprofit organizations, and reports on factors contributing to their success. The eleven cases studied illustrate that the establishment of commercial ventures in nonprofit organizations may result from either deliberate planning or following emergent opportunities. Regardless of whether change was emergent or deliberate, successful organizations were ones that did not try to radically change their paradigms. Their ventures were either merely an extension of existing physical or human resources, or entwined with their mission very early in their life cycle. The unsuccessful and struggling ventures, however, were the result of intended, deliberately planned change strategies that failed because the ventures failed to mesh with the organization's paradigm.

\section{Introduction}

The survival of nonprofit organizations depends to a large extent on their ability to garner the resources necessary to carry out their missions. In the past two decades, nonprofit organizations in Canada have experienced a sharp decline in their traditional sources of funding (Hall and Banting, 2000) and have been forced to adopt new strategies to ensure their continued operation, including revenue diversification through the development of commercial ventures (Foster and Meinhard, 2000; Froelich, 1999; Zimmerman and Dart, 1998). Running commercial ventures in nonprofit organizations involves an intriguing juxtaposition of values. Nonprofit organizations generally see their role as providing essential, health, social, cultural, educational or recreational services to specific clients or for the common good, without making a profit. Thus operating a venture intended to generate "profit-like" revenue borders on oxymoronic. It is not surprising then, that only a minority of nonprofit organizations in Canada engage in commercial ventures that involve more than just collecting fees for services. Estimates range from 8\% (Campbell, 1994, as cited in Zimmerman \& Dart, 1998:19) to 41\% (Hall, 1996). The strategic leap may be too daunting for many organizations. This paper investigates the change processes leading up to the adoption of commercial ventures as revenue generating alternatives in eleven nonprofit organizations, and reports on factors contributing to their success.

\section{Commercial Ventures and Social Enterprise}

While much has been written about nonprofits engaging in commercial activities, there is no clear consensus about either the exact boundaries of the term, or what these "commercial" activities should be called. The most common alternative term for commercial ventures is "social entrepreneurship" or "social enterprise". Although the two concepts overlap, they are not identical. 
It is difficult to pinpoint a definition of social enterprise because of the broad-ranging use of the term. However, most conceptualizations of social entrepreneurship or social enterprise include an aspect of innovation, or as Dart puts it, "frame-breaking" (Dart, 2004, p. 413). While this innovation is most often related to securing a financial outcome to help support the mission of a nonprofit organization, it does not necessarily have to do so. Thus for some, the primary characteristic of social enterprise is an innovative, pro-social activity focussing on the impact of the program. It may or may not involve financial gain for the organization, but even if it does, it still has to have a pro-social component (Dees, 2003; Emerson and Twersky, 1996; Leadbeater, 1997). Others focus more on the business and financial side, viewing social enterprise in nonprofit organizations as the adoption of business and marketing practices to ensure financial stability (Boschee, 2001; Weisbrod, 1998). It is this narrow use of the term social enterprise that is often used interchangeably with the term "commercial venture."

Commercial ventures refer to activities by nonprofit organizations designed to earn money for the organization in a way that is related to its mission (Skloot, 1987). They have been variously described by listing the types of activities included in the term. Zimmerman and Dart (1998), building from Skloot, (1987), identified commercial ventures as including: the sale of "program related products (e.g., Canadian Geographic Magazine), program related services (e.g., a snack bar in a museum), use of staff resources (e.g., social work staff serving paying as well as missionbased clients), use of client resources (e.g., sheltered workshop businesses), lease and rental of hard properties (e.g., office space downtime), licensing and use of soft property assets (e.g., mailing list rental), investments (e.g., partial equity stake in businesses managed by others), and full/partial business ownership"(p.iv).

Thus, although there is overlap in the use of the terms "commercial venture" and "social enterprise," some commercial ventures, for example, lease and rental of hard properties or investments, would clearly not be considered a social enterprise, using the criterion of innovation (Dees, 2003). At the other end of the spectrum, those social enterprises that are not income generating are clearly not commercial ventures.

As the title of this paper indicates, we use the term "commercial ventures" to describe the activities of the organizations that we studied. We do so because all of the activities described in our study involve financial goals. None of the activities falls into the category of non-financial innovation/entrepreneurship. The range of ventures studied includes non-innovative/nonentrepreneurial activities such as leasing space, as well as truly innovative commercial activities that easily fall into the category of social enterprise. Given that the addition a profit-making commercial activity is often diametrically opposed to the mission and essential strategic perspective of the organization, we seek to understand the process that resulted in the adoption of these ventures.

\section{Emergent versus Planned Change}

Nonprofit organizations in Canada are experiencing an unprecedented degree of environmental turbulence that is manifested in several ways: an increase in service demands because of government devolution; a decrease in government funding; replacement of operating 
grants with contract bidding, leading to increased competition not only with nonprofit, but also with for-profit organizations; increased demands for accountability; increased pressure to form partnerships and/or mergers (Meinhard and Foster, 2003; Meinhard, Foster and Berger, 2003); and decreasing numbers of volunteers (Canadian Centre for Philanthropy, 2000). Responses to countering the impact of these environmental changes include: downsizing, reduction of services, acquiring business and marketing skills at board and organizational level, collaborations with other organizations, and revenue diversification. Of these various strategies, resource diversification is the most common. Eighty percent of 645 nonprofit organizations sampled from across Canada reported actively pursuing revenue diversification strategies. These strategies include: seeking grants or donations from foundations, corporations or businesses; increasing fundraising efforts for individual donations; instituting or increasing user fees; generating revenue through special events; engaging in partnerships with other nonprofit or for-profit organizations in order to share resources; and engaging in commercial ventures of various sorts such as sales of goods or services or renting space (Foster \& Meinhard, 2005).

With the exception of engaging in commercial ventures, all of these revenue diversification activities are considered to be part of the routine activities of nonprofit organizations, particularly of charities. Different tactics and strategies may signal changes in organizational operations, but these changes are seldom either archetypal (Greenwood and Hinings, 1993) or paradigmatic (Pfeffer, 1978). Even though commercial ventures have been part of the nonprofit landscape for a long time, the establishment of a commercial venture for an individual organization might be considered to be a major paradigm shift as it involves new skill sets and different values (Dart, 2005; Zimmerman and Dart, 1998).

This study is an exploration of how different organizations have developed their commercial ventures. Organizational innovations and transformations can emerge incrementally (Morgan and Zohar, 2003) or they can be the result of deliberate strategic planning (Mintzberg, 1985). Specifically, we address two questions in this paper: a) Is there a relationship between the type of commercial venture and the type of change process? And b) Is there a relationship between the type of change process and the successful establishment of the commercial venture?

\section{Method}

\section{Definition of Commercial Venture}

For this study, a commercial venture is defined, after Skloot (1987), as any business- like activity undertaken by an organization to earn money towards furthering its mission, excluding fee-for-service revenues. We ascribe a very broad definition to commercial venture, ranging from the utilization of unused resources, such as leasing space, which would not be classified as an entrepreneurial endeavour, to true social enterprises which represent innovative programs designed to augment the mission while generating revenue. Thus, what we call a commercial venture may or may not be a social enterprise, as defined by Dees (2003), because we do not require innovation. 


\section{Sample}

The sample of organizations was attained through identifying and then contacting organizations with commercial ventures. Some organizations were contacted through referrals. While our sample is not random, we did achieve variety. The distribution of organizations in terms of size reflects the patterns reported in the literature, namely that large organizations are more likely to be involved in commercial ventures than small ones (Massarsky and Beinhacker, 2003). Our sample includes 2 small, 4 medium and 5 large organizations, where small is defined by an annual budget of under $\$ 500,000$, medium by an annual budget of $\$ 500,000-\$ 1,000,000$ and large by an annual budget of more than $\$ 1,000,000$.

In our sample we have four arts, cultural and recreation organizations, providing services to members and/or the general public in the areas of entertainment, culture and recreational programs and facilities; two religious-based organizations, providing religion- based services to the community; and five service-to-society organizations, providing a social service that benefits society. This distribution also reflects patterns reported in the literature, where arts and cultural organizations are the most likely to engage in commercial ventures, and religious organizations the least likely (Massarsky and Beinhacker, 2003).

All of our organizations are well established, with the youngest being in existence for 23 years and the oldest 110 years. Six organizations fall between the $20-70$ year range and five organizations fall between the $70-110$ year range. The ages of the commercial ventures range from 9 months to 65 years. Five ventures are less than 10 years old and six are more than 10 years old. Only two organizations were created as social enterprises, the rest took on the commercial venture at various times in their life-cycles.

Private donations and government funding are the predominant sources of funding for the organizations in this study. Only one organization reported that their various commercial ventures accounted for more that $50 \%$ of their revenues.

\section{Data Collection}

\section{Archival information}

Once an organization agreed to participate in the study, we combed their literature and websites to learn as much as we could about the organization and its venture.

\section{Interviews}

Eleven 60- 90 minute in-depth, semi-structured interviews were conducted by the authors. The respondents were key players of nonprofit organizations in Ontario involved in commercial ventures. The interviews took place over a period of eighteen months. Specifically, the interviews focused on the evolution of the enterprise in terms of business planning, financial support, organizational structure, success, and finally, the relationship between the "mother" organization and the venture. 


\section{Data analysis}

Most interviews were taped and transcribed. In two cases we were unable to tape, so detailed notes were taken. The transcribed interviews were content analysed by trained research assistants.

\section{Organizational Snapshots ${ }^{2}$}

Big City Church (BCC) relies mostly on funding from its own congregation. The Church has rented out unused or little-used property to community groups, arts groups and those who are in agreement with or neutral to the organization's mission. The Church's parking lot is also used for paid public parking to generate income for the organization. The rentals began as a response to requests, indicating an emergent strategy.

Café on the Promenade $(\mathrm{CoP})$ provides food service training and job opportunities for those who face barriers to employment, particularly mental health survivors. It was developed as a partnership between a local college and a church as a job placement program. Profits are used to supplement funding from the provincial government. This began as an entrepreneurial venture and involved intensive planning in partnership with a college and the government.

Campus Centre for Religion and Spirituality (CCRS) purchased a coffee shop franchise approximately five years ago primarily purposed to reach out to university students who would not otherwise visit the Centre. There was no active recruitment, but pamphlets were prominently displayed in their coffee shop. The coffee shop was closed three years later. This enterprise was the result of an intentional decision that involved consultation and the writing of a business plan.

Central European Cultural Club (CECC) provides social and recreational services to the Central European community. Five years ago the organization opened a restaurant for members only, but soon decided to separately incorporate it so that non-members could also be customers. The restaurant is currently struggling with taxation problems. The original members-only restaurant evolved from pot-luck events, but the incorporated restaurant was a result of a deliberate decision.

Food at Your Doorstep (FYD) provides meal delivery and companionship for terminally ill, convalescing, physically and mentally challenged individuals. FYD developed a strategic plan to prepare its own food rather than buying it from an outside catering firm. It separately incorporated a commercial catering company to prepare food for the organization's services and provide catering services to outside clients. Profits (minus overhead costs) are donated back into the organization.

21 Because of confidentiality requirements, the names of the organizations have been masked. 
Healthy Mother and Child (HMC) offers services and training to parents and child care providers. Five years ago the organization decided to expand their existing services by creating a forprofit nanny placement agency. A separate Board of Directors was appointed for the venture and a pilot project was launched. Problems encountered during the pilot project, convinced the Board that the venture was not consistent with the social mission of the organization and despite detailed strategic planning, the nanny placement agency never came to fruition.

Main Street Ethnic Community Centre (MSECC) provides recreation and community services to members of its own ethnic group and others. In response to requests, the organization began to rent out unused property to organizations that do not conflict in any way with its mission. In the beginning there were no rules or stipulations, and charges were minimal. With renovation of the property, and a new ED, rentals are more formally arranged. Thus an emergent strategy became solidified.

\section{Metropolitan Information Referral Services (MIRS) provides assessment,}

information, referral and advocacy services to a large city. Its nonprofit services include a community helpline offered 24 hours a day, an information database and companion website. MIRS' entrepreneurial activities include information portal services to government agencies, a published community services guide and information referral training workshops. The decision to commercialize flowed from requests for information and training.

The Metropolitan Symphony Centre (MSC) promotes Canadian artists and provides a venue in which they can perform. After moving to their new performing arts facility, senior management and the Board of Directors devised several revenue diversification strategies

- they hired an external company to manage their paid parking lot, offered event facilities and catering services and opened a music store housed within the facility. Although an extension of existing resources, there was clearly deliberation.

Puppet Magic (PM) provides performance, job, and life skills training to those who face barriers to employment, particularly the developmentally challenged. The organization received start-up funds from the government to initiate their unique puppet theatre. Performances not only provide experience for the members, but also generate profits to sustain the organization. Puppet Magic also markets its entertainment to corporate customers. This was a well-planned entrepreneurial project by a visionary leader who established strategic partnerships to ensure the creation of the organization.

Recycled Goods Depot (RGD) was initially created to provide care for Canadians with permanent physical disabilities. Approximately three years later, the organization decided to expand its mission to include employment and job skills training for the disabled through managing a thrift store, a photocopying service and a design centre. Planning was very carefully conducted, included trips abroad to learn from similar enterprises, and an inspiring vision. 


\section{Findings}

Analysis of the eleven organizations in the study clearly indicates that commercial ventures resulted from both emergent processes and deliberate, planned change. Furthermore, the sample very clearly was divided into two different types of commercial ventures. Four organizations were merely expanding the use of existing physical resources or expertise. BCC and MSECC were renting physical space. MIRS and MSC were selling their current expertise for commercial purposes. None of these ventures would be labeled entrepreneurial, as defined by the literature, as none of these initiatives was innovative. The remaining organizations fall into the category of true social enterprises, according to Dee's (2003) definition. The venture itself was an innovative idea, either pushing the organization beyond its existing mission or actually defining its mission. (Two of the organizations in our sample, Café on the Promenade and Puppet Magic, did not really undergo change. Their social enterprises were carefully planned and engaged at the founding of the organization.) As Table 1 illustrates, type of change, emergent or planned, is related to type of venture. None of the resource optimization ventures began as planned changes. For example, the opportunistic commercial ventures of BCC and MSECC were externally initiated by requests for use of space by individuals or other organizations. They evolved into more formal arrangements, but these activities were never part of explicit articulated change strategy. In the cases of MIRS and MSC, their first ventures were also evolutionary expansions of expertise. However, they spawned other commercial activities that were the result of more deliberate planning.

\begin{tabular}{|l|l|l|l|}
\hline & Emergent & Emergent $\rightarrow$ Planned & Planned \\
\hline $\begin{array}{l}\text { Resource } \\
\text { Optimization }\end{array}$ & BCC, MSECC & MIRS, MSC & \\
\hline Social Enterprise & & CECC & $\begin{array}{l}\text { CoP, CCRS, } \\
\text { FYD, HMC, PM, } \\
\text { RGD }\end{array}$ \\
\hline
\end{tabular}

Table 1. Distribution of Organizations According to Strategy and Enterprise Type

The entrepreneurial organizations, on the other hand, were initially more deliberate in their planning. For CoP and PM, the social enterprise is their mission. They were created as a result of careful strategic planning and partnerships with other organizations. Although RGD did not start out as a social enterprise, it made a deliberate strategic decision to change and incorporate a social enterprise project in its third year of existence. This was the result of intensive research in Canada and abroad. For these three organizations, mission and enterprise are one and the same.

CCRS, FYD and HMC decided to embark on commercial social enterprise later in their 
lifecycles. In two of the three cases, their Boards of Directors were fully involved in the decision and formal strategic and business plans were put into place. In the third case (CCRS), an intentional decision was made by management to engage consultants and to write a business plan. Finally, the enterprise at CECC began as a member-driven activity.

Later a decision was made to expand this venture and at this time the Board developed a formal business plan. For FYD and HMC, the enterprise was tangential to the mission. For the remaining two (CCRS, CECC), the enterprise was an attempt to further the mission by increasing and serving their membership.

Table 2 summarizes the findings and illustrates the relationships between type of venture and change processes, and change processes and success. Among the organizations adopting social enterprises, the three whose missions were totally integrated with the social enterprise were unequivocally successful. Among the other four, two were unequivocal failures (CCRS, HMC). The remaining two are still in operation; one is struggling to balance a huge debt created by property tax levies (CECC), and the other (FYD) is experiencing conflict between the main mission of the organization and the tangential enterprise. Interestingly, those organizations whose commercial ventures were only an optimization of existing resources, had unmitigated success, despite the fact that change was not planned.

\section{Discussion and Conclusions}

These case studies illustrate that the establishment of commercial ventures in nonprofit organizations may result from either deliberate planning or following emergent opportunities, and that there is a relationship between the type of venture undertaken, and the type of change involved. None of the resource optimization ventures were the result of deliberate strategy or planned change. They just emerged and evolved as opportunities arose. And they were all successful ventures. We attribute their success to the fact that their commercial ventures were not inimical to their deeply ingrained strategic perspective and did not conflict with their organizational paradigm. They did not change the nature of the organization or its operation. They were merely an extension of existing physical resources or expertise.

On the other hand, all of the ventures that were defined as entrepreneurial social enterprises were a result of intended, deliberately planned founding or change strategies. However, not all of them are successful. Two of the ventures were unmitigated failures, and two more are struggling. For each of these organizations, their social enterprises were neither supportive of nor integrated with the main mission. For two, the mission of the social enterprise was tangential, only vaguely related to the main mission, and involving separate activities, and only somewhat related skills. For the other two, the enterprises were set up to further the missions of their respective organizations, but the enterprises involved totally different activities and required new skills sets as well. For all of these organizations, the new ventures represented major paradigm shifts which they were not able to successfully negotiate (Greenwood and Hinings, 1993). 


\begin{tabular}{|c|c|c|c|c|}
\hline $\begin{array}{l}\text { Type of } \\
\text { venture }\end{array}$ & $\begin{array}{l}\text { Resource optimization commercial } \\
\text { (Big City Church, Metropolitan } \\
\text { Information Referral Services, } \\
\text { Metropolitan Symphony } \\
\text { Centre, Main St. Ethnic } \\
\text { Comm. Centre) }\end{array}$ & \multicolumn{3}{|c|}{$\begin{array}{l}\text { Social Enterprise } \\
\text { (Puppet Magic, Café on the Promenade, Recycled } \\
\text { Goods Depot, Food at your Doorstep, Healthy Mother } \\
\text { and Child, Central European Cultural Club, Campus } \\
\text { Centre for Religion and Spirituality }\end{array}$} \\
\hline Innovation & $\begin{array}{l}\text { No innovation, just optimizing } \\
\text { human and physical resources }\end{array}$ & \multicolumn{3}{|l|}{ Innovation } \\
\hline $\begin{array}{l}\text { Change } \\
\text { process }\end{array}$ & Emergent & \multicolumn{3}{|l|}{ Planned } \\
\hline Outcome & Successful (All) & Successful & \multicolumn{2}{|l|}{ Unsuccessful } \\
\hline $\begin{array}{l}\text { Relationship to } \\
\text { organization's } \\
\text { mission }\end{array}$ & $\begin{array}{l}\text { Supports mission only through } \\
\text { financial benefits } \\
\text { Does not clash with mission or } \\
\text { displace it }\end{array}$ & $\begin{array}{l}\text { Mission integration } \\
\text { (Puppet Magic, Café } \\
\text { on the Promenade, } \\
\text { Recycled Goods } \\
\text { Depot) }\end{array}$ & $\begin{array}{l}\text { Tangential to } \\
\text { mission (Food } \\
\text { at } \\
\text { your Doorstep } \\
\text { - surviving, } \\
\text { Healthy } \\
\text { Mother and } \\
\text { Child-folded) }\end{array}$ & $\begin{array}{l}\text { Furthering } \\
\text { mission } \\
\text { (Cen. Eur. } \\
\text { Cultural } \\
\text { Club - } \\
\text { surviving, } \\
\text { Campus } \\
\text { Centre for } \\
\text { Religion } \\
\text { and } \\
\text { Spirituality - } \\
\text { folded) }\end{array}$ \\
\hline $\begin{array}{l}\text { Stage in life- } \\
\text { cycle }\end{array}$ & Various stages of life cycle & Early in life cycle & Late cycle & Late cycle \\
\hline $\begin{array}{l}\text { Activity } \\
\text { integration }\end{array}$ & Separate activity & Integrated activity & $\begin{array}{l}\text { Separate } \\
\text { activity }\end{array}$ & $\begin{array}{l}\text { Separate } \\
\text { activity }\end{array}$ \\
\hline Skill congruence & $\begin{array}{l}\text { Management skills, outsourced or part } \\
\text { of general management duties of the } \\
\text { organization. Also in some } \\
\text { organizations, skill congruence. }\end{array}$ & $\begin{array}{l}\text { Skill congruence with } \\
\text { main organizational } \\
\text { mandate }\end{array}$ & $\begin{array}{l}\text { Venture } \\
\text { requires } \\
\text { different but } \\
\text { related skills }\end{array}$ & $\begin{array}{l}\text { Venture } \\
\text { requires new } \\
\text { unrelated } \\
\text { skills }\end{array}$ \\
\hline Motivation & Financial & Skills training & $\begin{array}{l}\text { Extending } \\
\text { mission }\end{array}$ & $\begin{array}{l}\text { Attraction } \\
\text { /outreach }\end{array}$ \\
\hline
\end{tabular}

Table 2. Summary of Results 
Interestingly, all of the organizations that used deliberate strategies, and whose social enterprises were ultimately successful, were ones whose enterprise and mission were entwined at birth. There was no clash of paradigms. Their creation was the result of visionary leadership imbued with foresight to ensure sustainability through strategic partnerships and commercial activities. In addition, their deliberate strategies exhibited scanning intensity and planning flexibility, considered essential to entrepreneurial ventures (Barringer and Bluedorn, 1999).

This study adds to the body of literature that contends that changes which do not involve major paradigm shifts are more easily implemented and are more likely to succeed. In addition, these results offer guidance to nonprofit practitioners. During this time of funding cutbacks and increased demand for services, there is much pressure on nonprofit organizations to increase revenue by diversifying sources. Embarking on a commercial venture is one option that has much appeal. However, our results suggest that nonprofits proceed with caution and consider commercial activities that are consistent with their current mission. When the gap between the core mission and the enterprise is too large, it is difficult for a nonprofit to make the strategic leap successfully.

\section{References}

Barringer, B.R. and Bluedorn, A.C., "The Relationship between Corporate Entrepreneurship and Strategic Management," Strategic Management Journal, 21(1999), 421-444.

Boschee, J. The Social Enterprise Sourcebook, Minneapolis: Northland Institute, 2001.

Campbell, D.R., The First General Map of Canada's Third Sector, Report No. 94-03, School of Policy Studies, Kingston: Queen's University, 1994.

Canadian Centre for Philanthropy. National Survey of Giving, Volunteering and Participating, On-line. (click here)

Dart, R. "The Legitimacy of Social Enterprise." Nonprofit Management and Leadership, 14 (2004), 411-424.

Dees, J.G., "Social Entrepreneurship is About Innovation and Impact, Not Income," Social Edge Online. [skoll.socialedge.org/] 2003.

Emerson J. and Twersky F. (Eds.), New Social Entrepreneurs: The Success, Challenge and Lessons of Nonprofit Enterprise Creation, San Francisco: Roberts Foundation, 1996. 
Foster, M. and Meinhard, A., 'Diversifying Revenue Sources in Canada: Are Women's Voluntary Organizations Different?" Nonprofit Management and Leadership, Forthcoming, 2005.

Froelich, K., "Diversification of Revenue Strategies: Evolving Resource Dependence in Nonprofit Organizations," Nonprofit and Voluntary Sector Quarterly, 28, (1999), 246-268.

Greenwood, R. and Hinings, C.R. "Understanding Strategic Change: The Contribution of Archetypes”. Academy of Management Journal; 1993; 36, 1052-1081

Hall, M., Charitable Fundraising in Canada, Toronto: Canadian Centre for Philanthropy, 1996.

Hall, M. and Banting, K.G., The Nonprofit Sector in Canada: An Introduction. In K.G. Banting (Ed.), The Nonprofit Sector in Canada: Roles and Relationships, Montreal and Kingston: School of Policy Studies, Queen's University, 2000, 1-28. Leadbeater, C., The Rise of the Social Entrepreneur, London: Demos, 1997. Massarsky, C.V. and Beinhacker, S.L., Enterprising Nonprofits: Revenue Generation in the Nonprofit Sector, Yale School of Management - The Goldman Sachs Foundation Partnership on Nonprofit Ventures; conducted for The Pew Charitable Trust, 2003.

Meinhard, A. and Foster M. "Differences in the Response of Women's Voluntary Organizations to Shifts in Canadian Public Policy". Nonprofit and Voluntary Sector Quarterly, 2003, 32 (3), 366-396.

Meinhard, A., Foster, M. and Berger, I. The Evolving Relationship Between Government and the Voluntary Sector in Ontario. Presented at the annual conference of the Association for Research on Nonprofit Organizations and Voluntary Action, Denver, CO, November, 2003.

Mintzberg H. and Waters, J.A. Of Strategies: Deliberate and Emergent. Strategic Management Journal, 6 (1985), 257-272.

Morgan, G. and Zohar, A. Achieving Quantum Change: Incrementally!! Accessed April 12, 2005. www.imaginiz.com/abstract. Modified 2003.

Skloot, E., Enterprise and Commerce in Nonprofit Organizations. In W. Powell, (ed.) The Nonprofit Sector: A Research Handbook, New Haven: Yale University Press, 1987, 380-393. 
Weisbrod, B., To profit or not to profit: The commercial transformation of the nonprofit sector, Cambridge: Cambridge University Press, 1998.

Zimmerman, B. and Dart, R., Charities Doing Commercial Ventures: Societal and Organizational Implication. Toronto: Canadian Policy Research Network and the Trillium Foundation, 1998. 